\title{
Awareness, Prevention and Precaution among Dentists Regarding COVID-19
}

\author{
Sirisha Sampangi Pushpa ${ }^{1}$, Nimmi Janardhanan ${ }^{2}$, Shivaprasad Bilichodmath ${ }^{3}$
}

\begin{abstract}
Background: Coronavirus disease-2019 (COVID-19) has metamorphosed itself into a life-threatening and pressing issue of the day; moreover, it has challenged health professions and systems and has evoked different speeds of reaction and types of response around the world. The transmission of virus via contact with droplets and aerosols generated during dental clinical procedures and chances of cross-contamination pose high risk. This is where the role of dental professionals crop-up in preventing the transmission of COVID-19. Hence, this survey aims to gauge the awareness, prevention, and precaution among dentists regarding COVID-19 by circulating the questionnaire among the dental practitioners and clinicians mostly in Bengaluru, Karnataka.

Materials and methods: A questionnaire-based survey was conducted which consisted of 22 questions. A total of 122 active participants were included in the study.

Results: Everyone was apprehensive of COVID-19 and its brief history. A majority (108) of the participants had information principally from social media as their main source followed by the newspaper, well-versed knowledge that it affects the respiratory system and it is absolutely necessary to follow protocols for prevention. Unseeming paradoxical views was noted on the influence of social media. A compelling response was noted when asked regarding patient concern during the dental procedures. In all, $34.5 \%$ agreed on no, $37.2 \%$ agreed on yes, and $28.1 \%$ were on a maybe. The participating group is also aware of the appropriate precautionary measures to be taken. In all, $81.7 \%$ of the participants comply with the $\mathrm{N}-95$ respirator while treating the patients. The most pliable option in combating COVID-19 would be to stay safe and furnish elite information and precautions to the patients and the society.

Conclusion: Preponderance of the dentists are aware of the virus, its survival, and its complications. We should also clear the facts on the vulnerability of COVID-19. Although chlorhexidine is a widely used disinfectant and antiseptic, hydrogen peroxide and glutaraldehyde are said to be the best disinfectants to combat against the virus. The patient may be worried to opt for any procedure, but it should be the responsibility of the dentist to manage and follow proper protocol to disinfect and sterilize the equipment to minimize patient infection and cross-contamination. Nonetheless, it is important to stress on the personal protective equipment (PPE) usage. Strictly speaking, it may not be the need of the hour to continue dental care; however, we should not hesitate to attend emergencies.
\end{abstract}

Keywords: Awareness, COVID-19, Cross-contamination, Dentistry, Pandemic, Personal protective equipment, Prevention.

Journal of Health Sciences \& Research (2020): 10.5005/jp-journals-10042-1091

\section{INTRODUCTION}

The word "coronavirus" was coined in 1968 and is derived from "corona"-like or crown-like morphology perceived for these viruses in the electron microscope. ${ }^{1}$ In 1975, the International Committee on the Taxonomy of Viruses established the Coronaviridae family. Several coronaviruses have caused consequences in humans and animals in the past two decades. ${ }^{2}$ The best-known examples are severe acute respiratory syndrome coronavirus (SARS-CoV), Middle East respiratory syndrome coronavirus (MERS-CoV), and porcine epidemic diarrhea virus (PEDV). In densely populated areas, urbanization and the increasingly frequent mixing of various animals may have encouraged the emergence and reemergence of some of these viruses. ${ }^{3}$

A cluster of pneumonia deaths, caused by a newly identified $\beta$-coronavirus, occurred in Wuhan, China, in December 2019. This coronavirus was originally named as the 2019 novel coronavirus (2019-nCoV) on January 12, 2020, by the World Health Organization (WHO). The WHO officially named the disease as the 2019 coronavirus disease-2019 (COVID-19), and the International Committee's Coronavirus Research Group (CSG) proposed to name the new coronavirus as SARS-CoV-2, both of
${ }^{1}$ Department of Oral and Maxillofacial Surgery, Bapuji Dental College and Hospital, Davangere, Karnataka, India

2,3 Department of Periodontics, RajaRajeshwari Dental College and Hospital, Bengaluru, Karnataka, India

Corresponding Author: Shivaprasad Bilichodmath, Department of Periodontics, RajaRajeshwari Dental College and Hospital, Bengaluru, Karnataka, India, Phone: +919900511071, e-mail: drshivaprasadbm@ gmail.com

How to cite this article: Pushpa SS, Janardhanan N, Bilichodmath S. Awareness, Prevention and Precaution among Dentists Regarding COVID-19. J Health Sci Res 2020;11(1):27-36.

Source of support: Nil

Conflict of interest: None

which were released on February 11, 2020. The Chinese scientists rapidly isolated a SARS-CoV-2 strain from a patient within a brief time on January 07,2020 , and came out to genome sequencing for the SARS-CoV-2. ${ }^{4}$

The new COVID-19 originates from the SARS-CoV-2 virus. The most likely biological reservoirs for SARS-CoV-2 are bats, but it is suspected that from another intermediate animal host, the virus

(c) The Author(s). 2020 Open Access This article is distributed under the terms of the Creative Commons Attribution 4.0 International License (https://creativecommons. org/licenses/by-nc/4.0/), which permits unrestricted use, distribution, and non-commercial reproduction in any medium, provided you give appropriate credit to the original author(s) and the source, provide a link to the Creative Commons license, and indicate if changes were made. The Creative Commons Public Domain Dedication waiver (http://creativecommons.org/publicdomain/zero/1.0/) applies to the data made available in this article, unless otherwise stated. 
crossed the species barrier to humans. This intermediate host animal may be a domestic animal, a wild animal, or a domesticated wild animal that has not been identified yet. Research is currently under way to determine the viability and survival period of SARS-CoV-2. ${ }^{5}$ Coronaviruses are generally very stable in a frozen state according to studies of other coronaviruses which showed survival at $-20^{\circ} \mathrm{C}$ for up to 2 years. Studies carried out on SARSCoV and MERS-CoV suggest that, depending on a combination of parameters such as temperature, humidity and light, these viruses can survive on various surfaces for up to several days. For instance, at refrigeration temperature $\left(4^{\circ} \mathrm{C}\right), \mathrm{MERS}-\mathrm{CoV}$ can remain viable up to 72 hours. Current research on other strains of coronaviruses suggests that while coronaviruses tend to be stable for a certain time at low and freezing temperatures, food hygiene and good food safety practices can prevent their foodborne transmission. Coronaviruses are thermolabile, which means that they are susceptible to normal cooking temperatures $\left(70^{\circ} \mathrm{C}\right)$. Thus, as a general rule, the consumption of raw or undercooked animal products should be avoided. Raw meat, raw milk, or raw animal organs should be handled with care to avoid cross-contamination with uncooked foods. ${ }^{5}$

Most people infected with the COVID-19 virus will develop mild to moderate respiratory disease and recover without any special treatment being needed. Older people and those with underlying health conditions, such as cardiovascular disease, diabetes, chronic respiratory disease, and cancer, are more likely to experience significant illness. Most common symptoms include fever, dry cough, and fatigue. Less common symptoms include aches and pains, sore throat, diarrhea, conjunctivitis, headache, loss of taste or smell, skin rash, or finger or toe discoloration, while extreme symptoms include trouble breathing or shortness of breath, chest pain or strain, loss of speech, or motor function. ${ }^{6}$ The respiratory infections can be transmitted through droplets of varying sizes: when the droplet particles are $>5-10 \mu \mathrm{m}$ in diameter, they are referred to as respiratory droplets, and when $<5 \mu \mathrm{m}$ in diameter, they are referred to as droplet nuclei. ${ }^{7}$ According to present affirmations, COVID-19 virus is primarily transmitted among people through respiratory droplets and contact routes. ${ }^{8-13}$ In an analysis of 75,465 COVID-19 cases in China, airborne transmission was not reported. ${ }^{13}$

Droplet transmission occurs when a person is in close contact (within $1 \mathrm{~m}$ ) with someone who has respiratory symptoms (e.g., coughing or sneezing) and is thus at risk of exposure to potentially infectious respiratory droplets through his/her mucosa (mouth and nose) or conjunctive (eyes). In the immediate environment, transmission can also occur through fomites around the infected person. ${ }^{14}$ Thereby, COVID-19 transmission can occur by direct contact with infected people and indirect contact with surfaces in immediate environment or with objects used on infected person (e.g., stethoscope or thermometer). ${ }^{15}$

Airborne transmission varies from droplet transmission, as it refers to the presence of microbes within droplet nuclei, which are usually considered to be particles $<5 \mu \mathrm{m}$ in diameter, which can stay in the air for long periods of time and be distributed over distances greater than $1 \mathrm{~m}$ to others. In relation to COVID-19, airborne transmission may be feasible under specific circumstances and settings in which procedures or support treatments that generate aerosols are performed, i.e., endotracheal intubation, bronchoscopy, open suctioning, administration of nebulized treatment, manual ventilation before intubation, turning the patient to the prone position, disconnecting the patient from the ventilator, noninvasive positive-pressure ventilation, tracheostomy, and cardiopulmonary resuscitation. ${ }^{15}$

Based on the available data, including recent publications, the WHO continues to recommend droplet and contact precautions for those caring for COVID-19 patients and airborne precautions for the circumstances and settings in which aerosol-generating procedures and support care are carried out according to risk assessment. ${ }^{16}$

Current recommendations of the WHO emphasize the importance of the reasonable and effective use of all personal protective equipment (PPE) ${ }^{17}$ and not only masks that require the correct and rigorous conduct of healthcare workers, particularly in procedures for doffing and hand hygiene. ${ }^{18}$ The WHO also recommends training for staff on these suggestions as well as appropriate procurement and availability of the PPE, other supplies and facilities available. ${ }^{19}$ Ultimately, the WHO continues to stress the importance of regular hand hygiene, respiratory etiquette, and environmental cleaning and disinfection as well as the importance of maintaining physical distances and avoiding direct, unprotected contact with people with fever or respiratory symptoms. ${ }^{15}$

Given the widespread transmission of SARS-CoV-2 and its dissemination to healthcare providers, ${ }^{20,21}$ dental professionals are at high risk of nosocomial infection and may become possible disease carriers.

These risks can be due to the particular nature of dental procedures, including the generation of aerosols, the handling of sharps, and the proximity of the provider to the oropharyngeal area of the patient. Additionally, if sufficient measures are not taken, the patients can potentially be exposed to cross-contamination by dental offices. Dental practices should be better prepared to recognize a probable COVID-19 infection and refer patients with suspected, confirmed, or a history of COVID-19 infection to appropriate treatment centers, as the understanding of this novel disease progresses. ${ }^{22}$

Considering the current situation, we conducted a questionnaire survey among the oral healthcare professionals, with the aim of understanding the awareness, prevention, and precautions undertaken among dental professionals regarding COVID-19 pandemic.

\section{Materials and Methods}

The present cross-sectional study was conducted using an online survey questionnaire from March 27, 2020, till April 29, 2020. For this a well-constructed survey, link was circulated through Google doc, and an e-mail was sent to the dental professionals. All the participants were informed about the purpose and scope of the study, and those who agreed the terms were considered in this study. Responses were received from 122 dentists and clinical practitioners via online. The participants were mostly from Bengaluru, Karnataka.

The questionnaire for the survey included trichotomous (yes, no, maybe) /close-ended questions, open-ended questions, multiplechoice questions, semantic differential scale questions, and staple scale questions. The results were analyzed using percentage. The statistical analysis was also done on SPSS version 25. 


\section{DATA}

Are you aware of COVID-19?

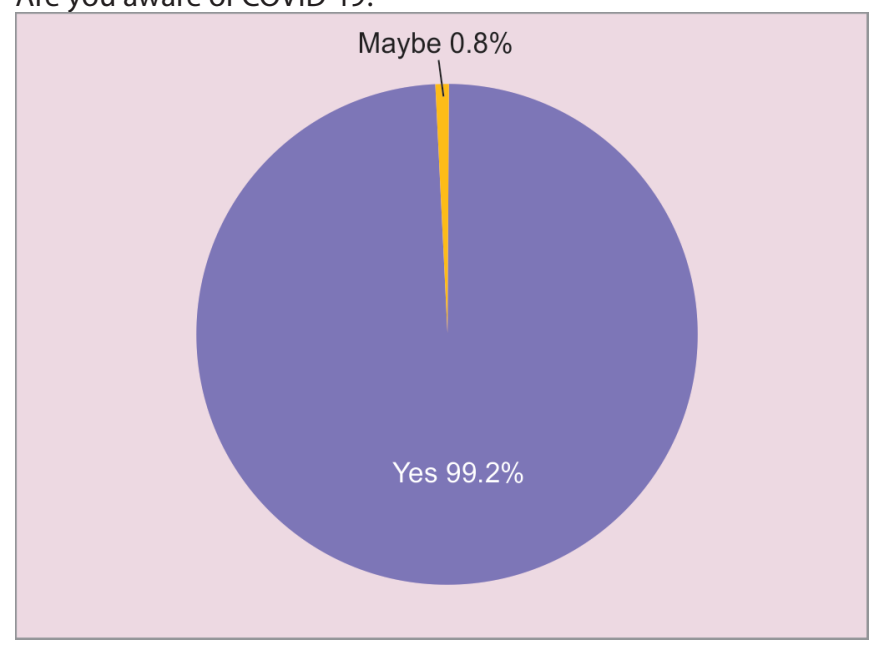

How did you know about COVID-19?

COVID-19 is vulnerable to?

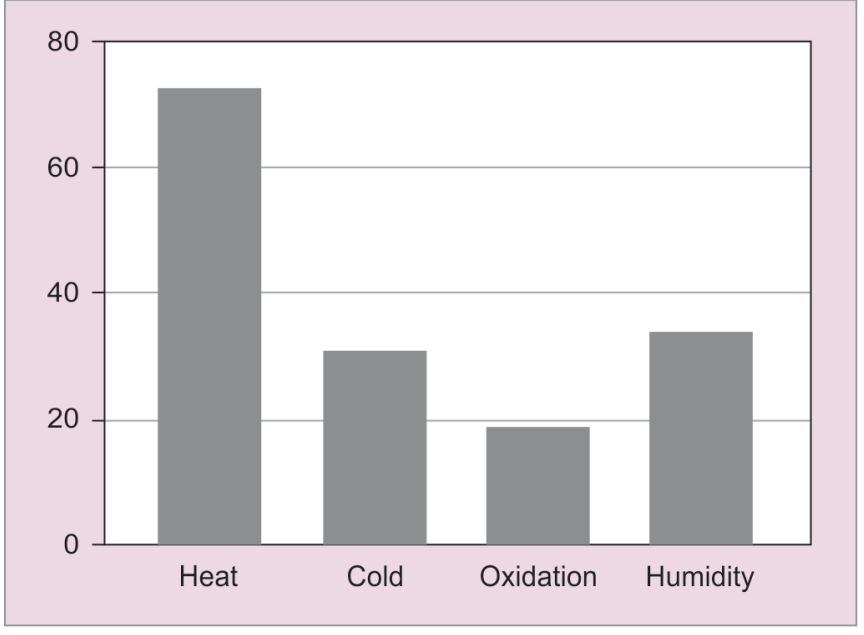

COVID-19 stands for

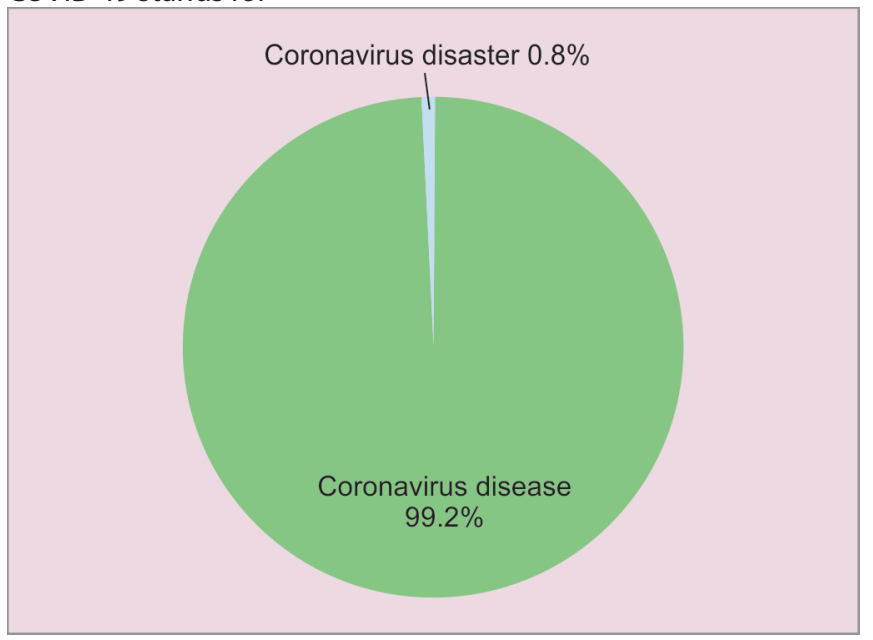

It is called COVID-19 because

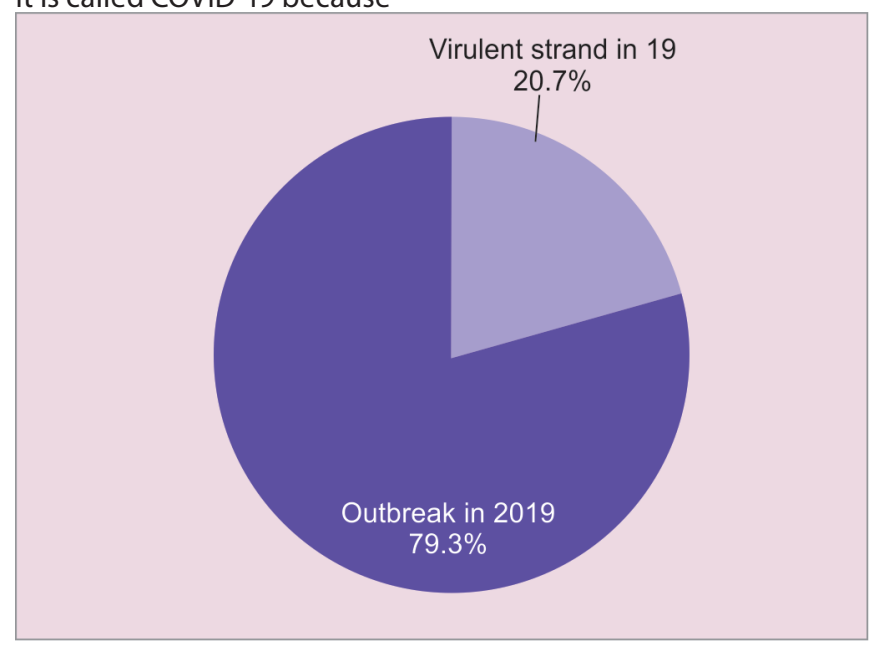

COVID-19 is considered as

by WHO

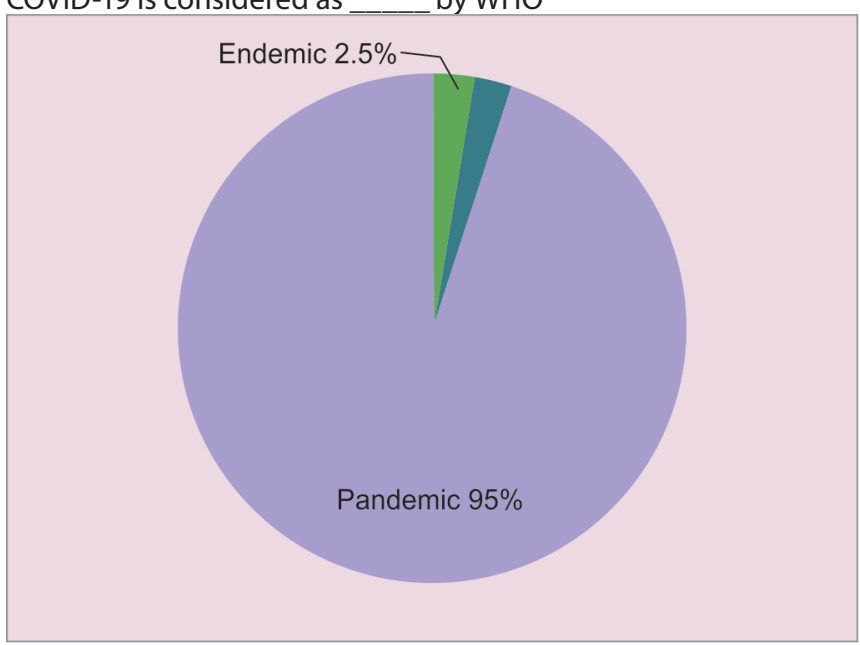


Where did the outbreak of virus take place?

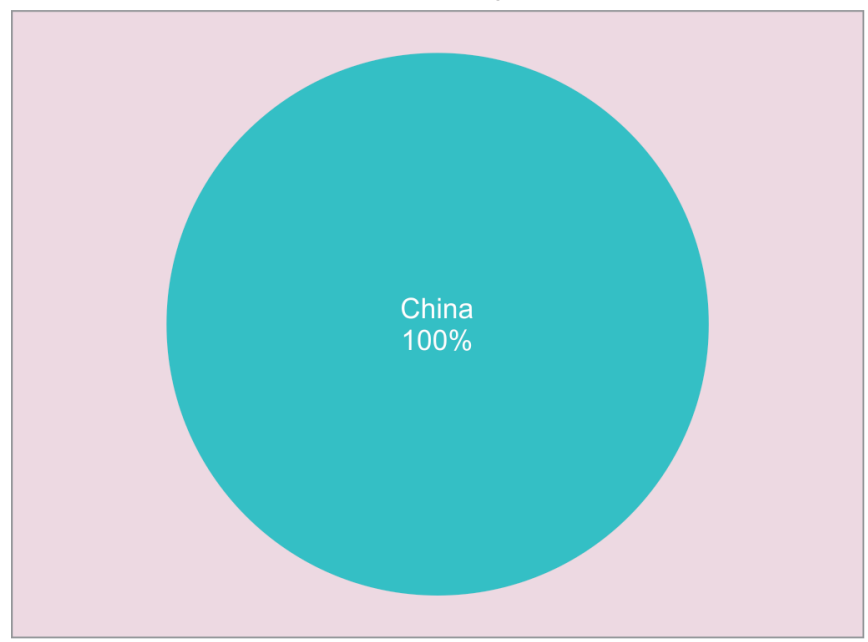

\section{COVID-19 mainly affects}

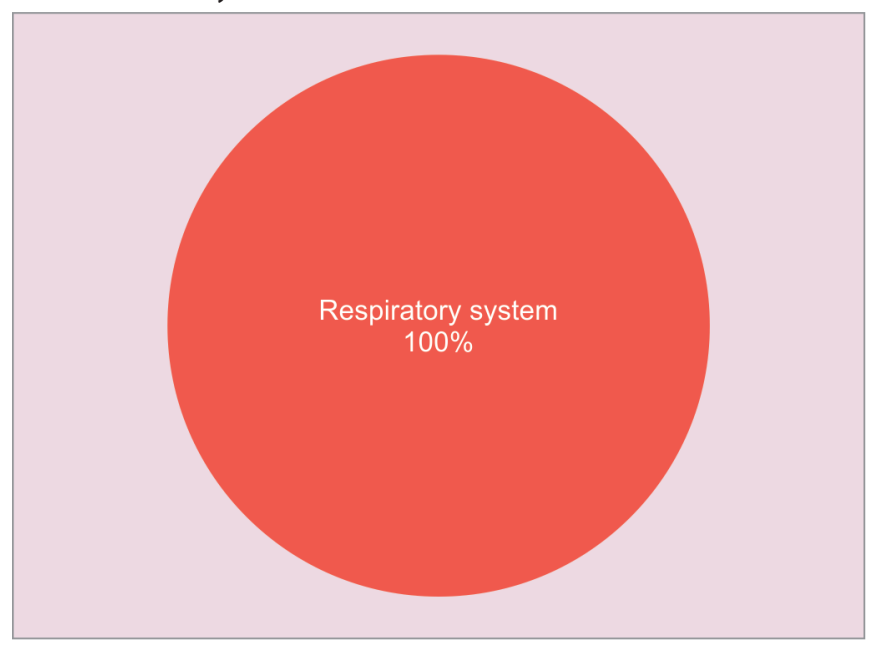

Is it necessary to continue practicing at the heat of the moment?

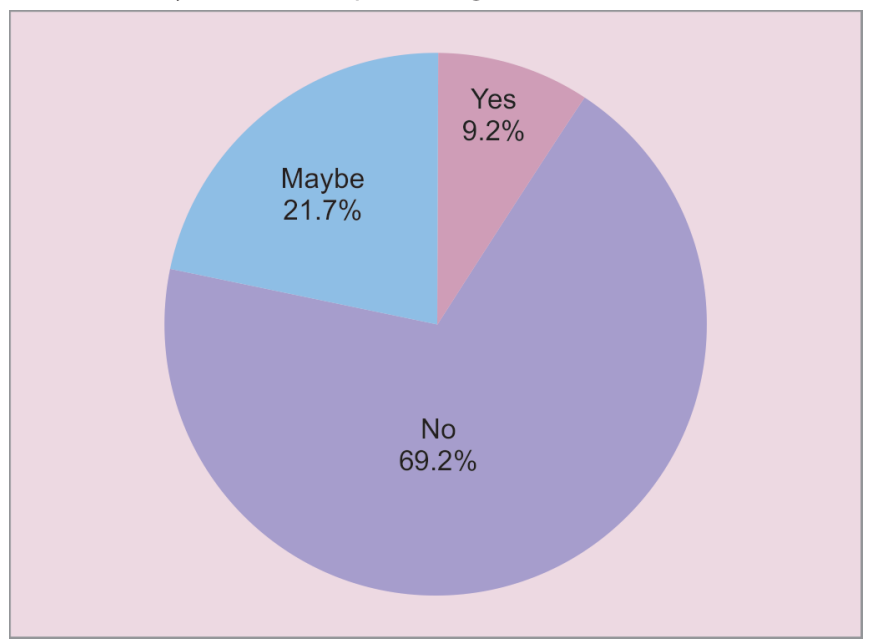

\section{Signs and symptoms of COVID-19}

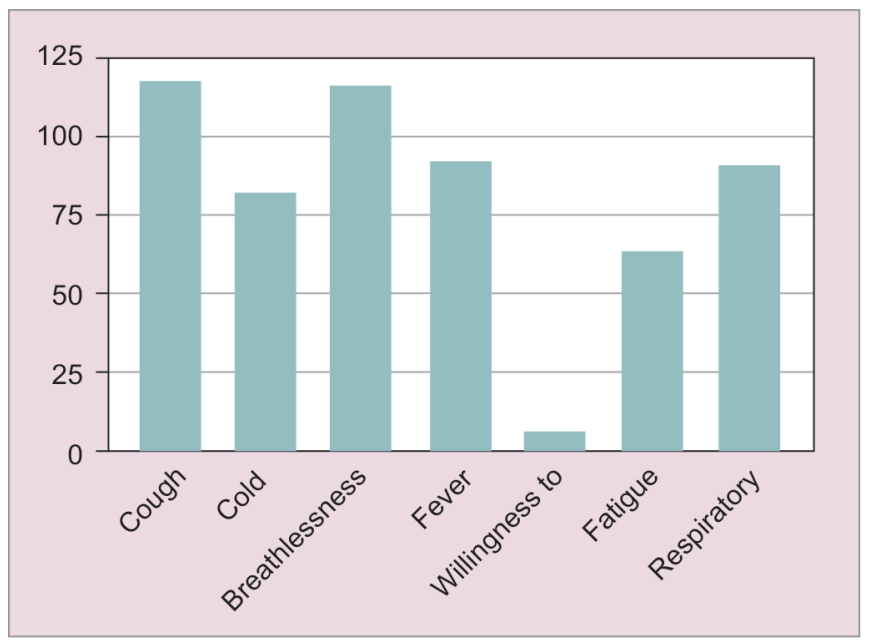

\section{Best means of management of COVID-19?}

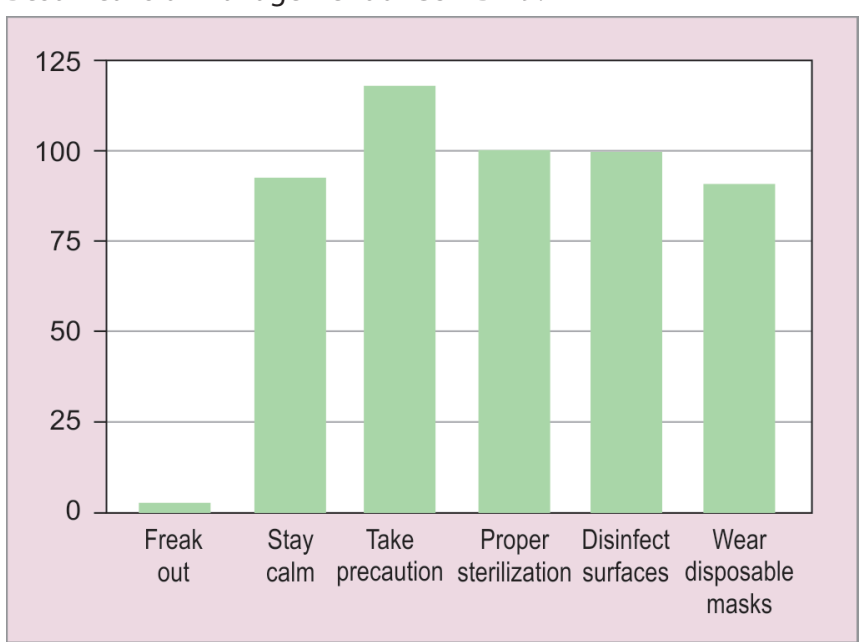

Influence of social media on COVID-19?

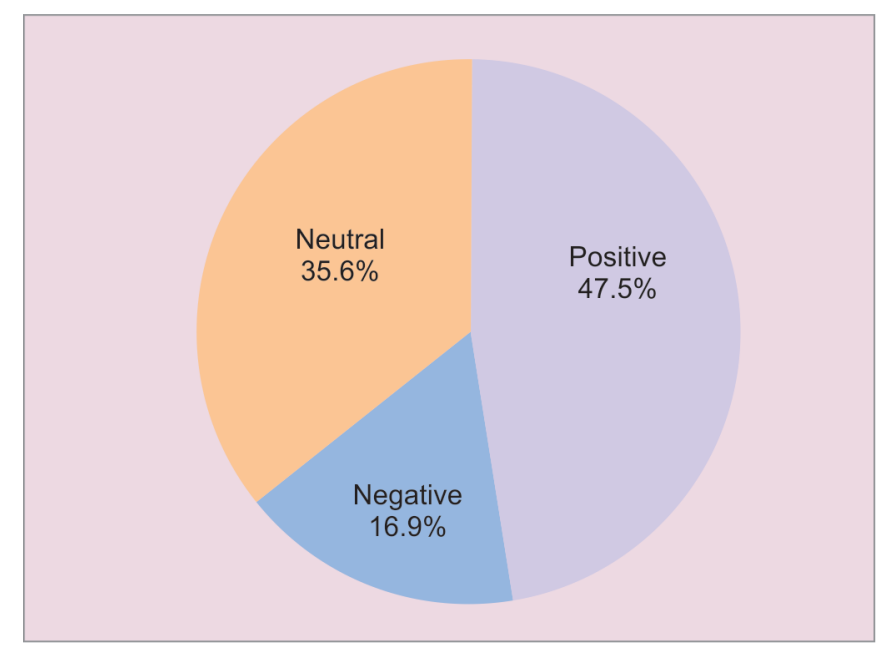




\section{Best platform for latest information on COVID-19}

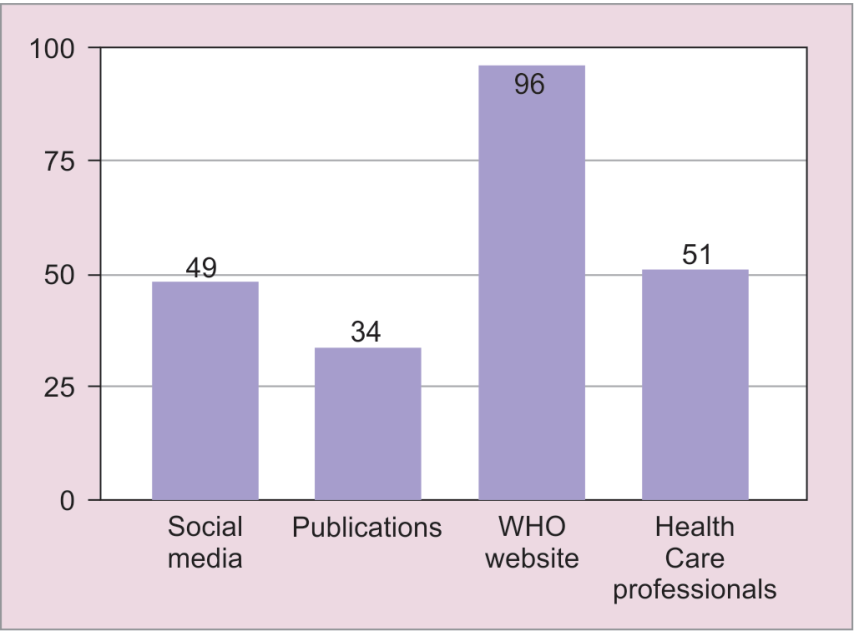

\section{Precautions to be taken to avoid COVID-19?}

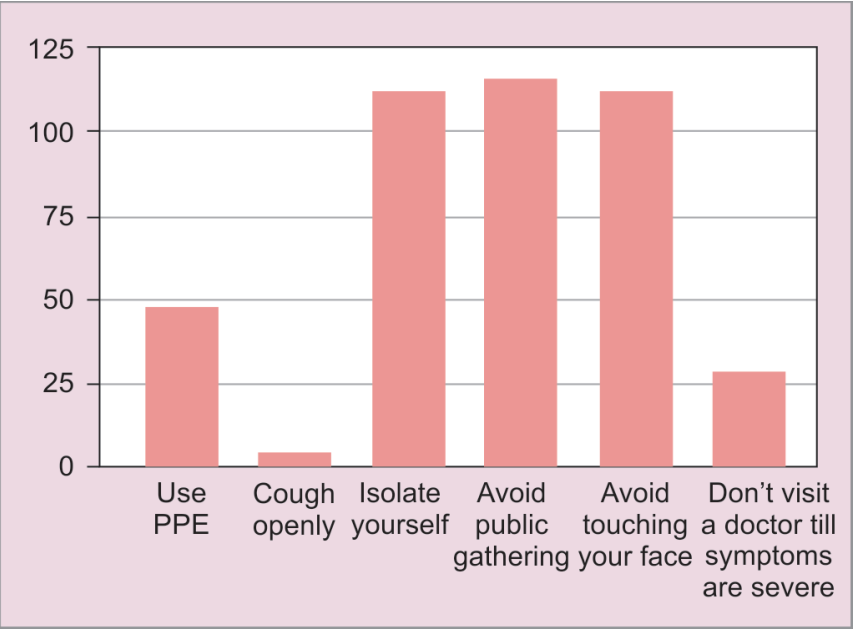

Most vulnerable group of people to COVID-19?

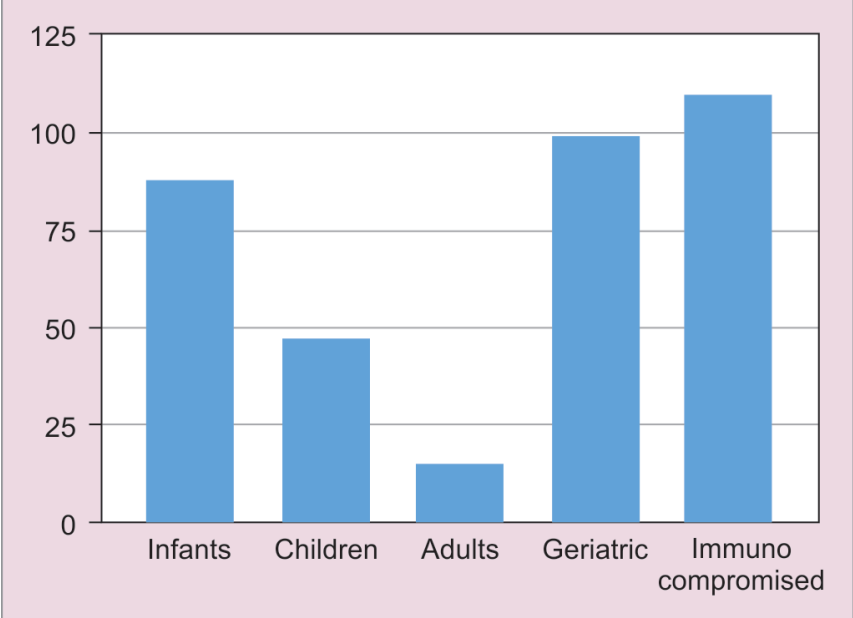

Should the patient be worried to undergo any procedure?

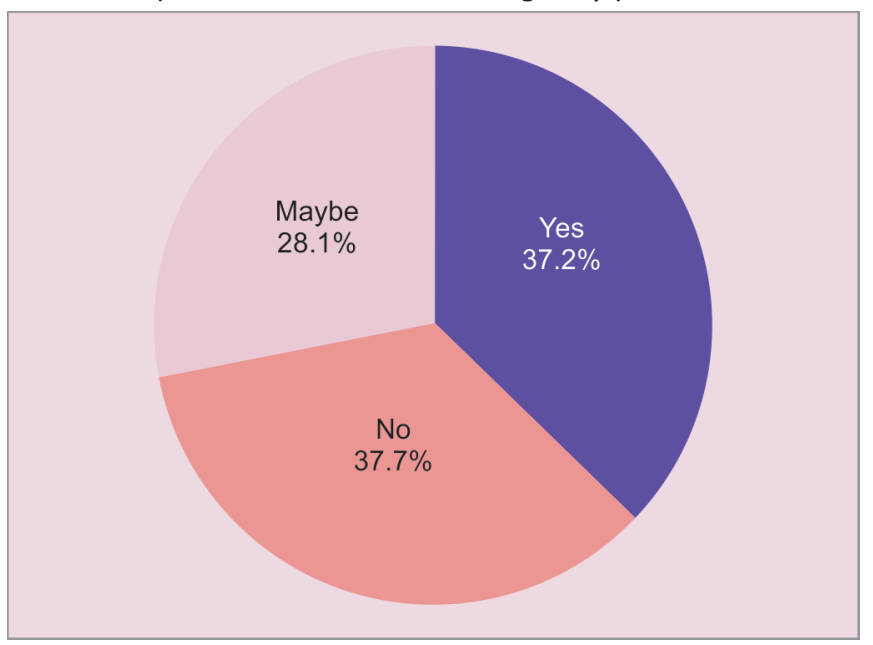

Patients to be advised to rinse using?

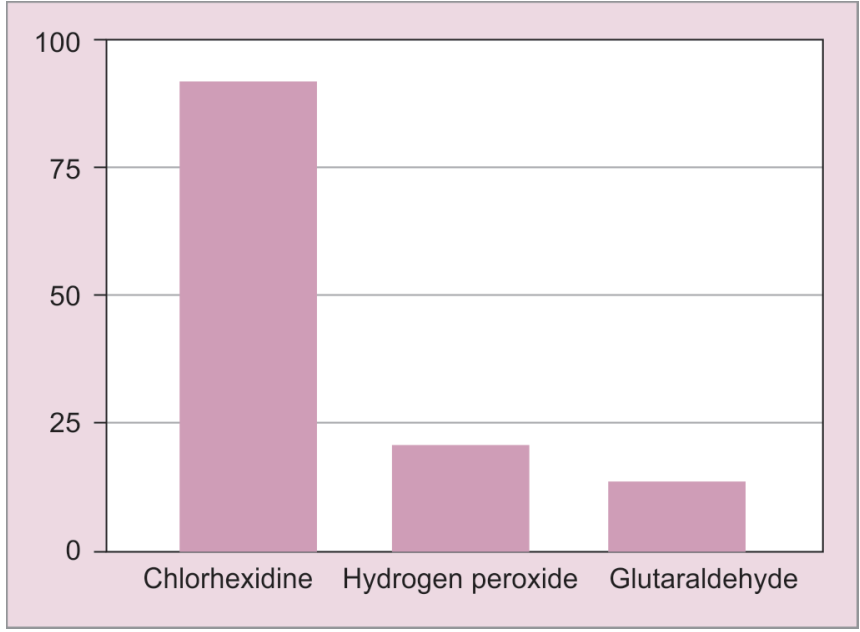

Should the dentist wear N-95 while treating patients?

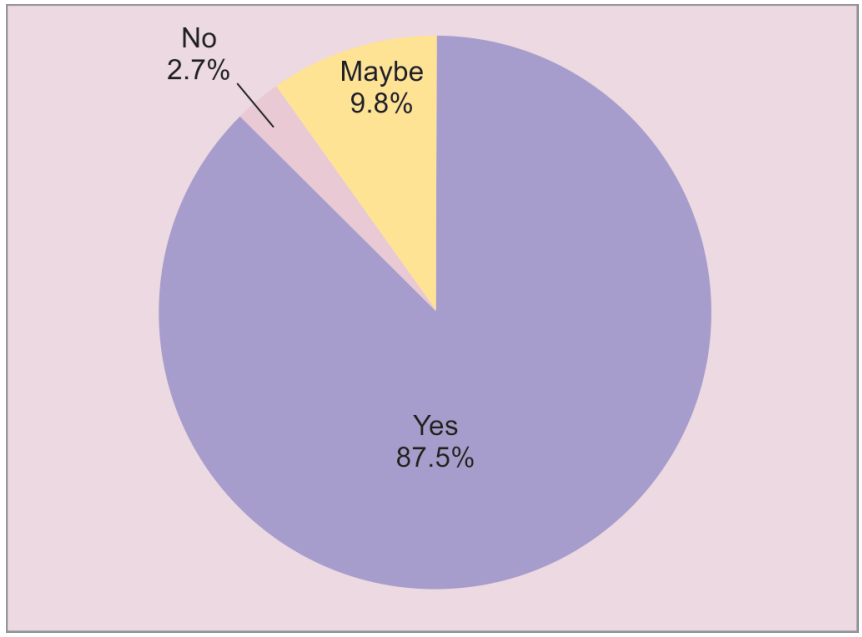


Should you be worried about COVID-19?

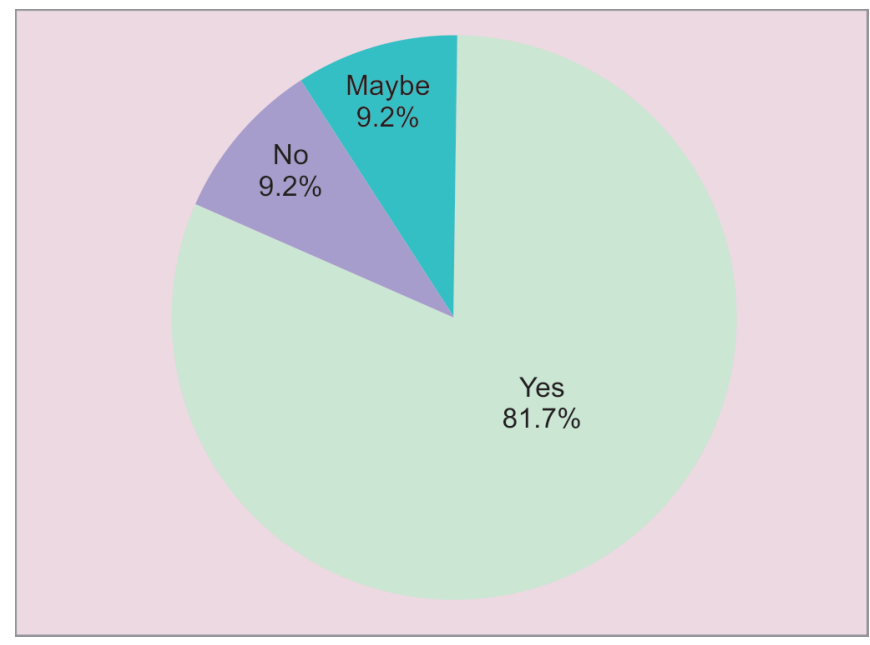

What would you tell your patient about COVID-19?

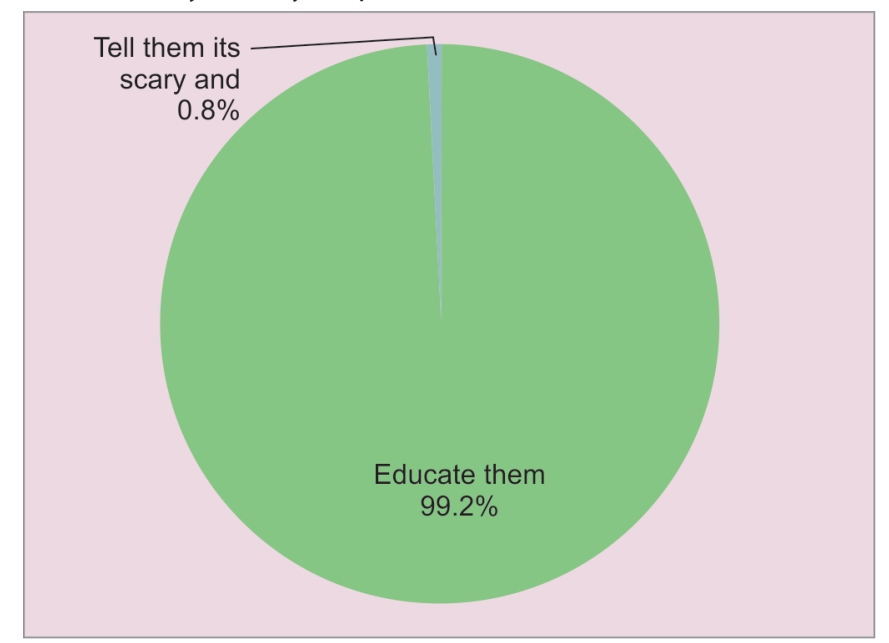

\begin{tabular}{|c|c|c|c|c|}
\hline \multirow[t]{2}{*}{ question_Q1 } & \multirow[t]{2}{*}{ Categorical } & \multirow[t]{2}{*}{ Are you aware of COVID-19? (A-Yes, B-Maybe) } & $A-121$ & $99.2 \%$ \\
\hline & & & B-1 & $0.8 \%$ \\
\hline \multirow[t]{5}{*}{ question_Q2 } & \multirow[t]{5}{*}{ Categorical } & \multirow{5}{*}{$\begin{array}{l}\text { How did you know about COVID-19? (A-Newspaper, B-Social media, C- } \\
\text { Healthcare Professionals, D-Friends, E-Others) }\end{array}$} & $A-63$ & $51.6 \%$ \\
\hline & & & B-110 & $90.2 \%$ \\
\hline & & & $C-54$ & $44.3 \%$ \\
\hline & & & D-40 & $32.8 \%$ \\
\hline & & & E-14 & $11.5 \%$ \\
\hline \multirow[t]{5}{*}{ question_Q3 } & \multirow[t]{5}{*}{ Categorical } & \multirow{5}{*}{$\begin{array}{l}\text { What is the virus that causes COVID-19? (A-Coronavirus, B-SARS-CoV-2, } \\
\text { C-Novel coronavirus, D-COVID 19, E-Other) }\end{array}$} & A-98 & $80.3 \%$ \\
\hline & & & B-11 & $9.0 \%$ \\
\hline & & & C-9 & $7.4 \%$ \\
\hline & & & D-3 & $2.5 \%$ \\
\hline & & & $\mathrm{E}-1$ & $0.8 \%$ \\
\hline \multirow[t]{2}{*}{ question_Q4 } & \multirow[t]{2}{*}{ Categorical } & \multirow[t]{2}{*}{ COVID stands for. (A-Coronavirus Disease, B-Coronavirus disaster) } & $A-121$ & $99.2 \%$ \\
\hline & & & B-1 & $0.8 \%$ \\
\hline \multirow[t]{2}{*}{ question_Q5 } & \multirow[t]{2}{*}{ Categorical } & \multirow{2}{*}{$\begin{array}{l}\text { It is called as COVID-19 because (A-Outbreak was reported in 2019, } \\
\text { B-Virulent factor of virus is in strand 19) }\end{array}$} & A-98 & $80.3 \%$ \\
\hline & & & B-24 & $19.7 \%$ \\
\hline \multirow[t]{3}{*}{ question_Q6 } & \multirow[t]{3}{*}{ Categorical } & \multirow{3}{*}{$\begin{array}{l}\text { COVID-19 is considered as by WHO (A-Pandemic, B-Epidemic, } \\
\text { C-Endemic) }\end{array}$} & A-116 & $95.1 \%$ \\
\hline & & & $\mathrm{B}-3$ & $2.5 \%$ \\
\hline & & & $\mathrm{C}-3$ & $2.5 \%$ \\
\hline \multirow[t]{4}{*}{ question_Q7 } & \multirow[t]{4}{*}{ Categorical } & \multirow{4}{*}{$\begin{array}{l}\text { Where did the outbreak of the virus take place? (A-China, B-United } \\
\text { States, C-Italy, D-India) }\end{array}$} & A-122 & $100.0 \%$ \\
\hline & & & $\mathrm{B}-0$ & $0.0 \%$ \\
\hline & & & $\mathrm{C}-\mathrm{O}$ & $0.0 \%$ \\
\hline & & & $\mathrm{D}-0$ & $0.0 \%$ \\
\hline \multirow[t]{7}{*}{ question_Q8 } & \multirow[t]{7}{*}{ Categorical } & \multirow{7}{*}{$\begin{array}{l}\text { Signs \& Symptoms of COVID-19? (A-Cough, B-Cold, C-Breathlessness, } \\
\text { D-Fever, E-Willingness to travel, F-Fatigue, G-Respiratory distress) }\end{array}$} & $A-120$ & $98.4 \%$ \\
\hline & & & B-82 & $67.2 \%$ \\
\hline & & & $C-118$ & $96.7 \%$ \\
\hline & & & D-93 & $76.2 \%$ \\
\hline & & & $E-6$ & $4.9 \%$ \\
\hline & & & $F-65$ & $53.3 \%$ \\
\hline & & & G-92 & $75.4 \%$ \\
\hline \multirow[t]{3}{*}{ question_Q9 } & \multirow[t]{3}{*}{ Categorical } & \multirow{3}{*}{$\begin{array}{l}\text { COVID-19 mainly affects (A-Respiratory system B-Cardiovascular system, } \\
\text { C-Renal system) }\end{array}$} & $A-122$ & $100.0 \%$ \\
\hline & & & $\mathrm{B}-0$ & $0.0 \%$ \\
\hline & & & $\mathrm{C}-0$ & $0.0 \%$ \\
\hline
\end{tabular}




\begin{tabular}{|c|c|c|c|c|}
\hline \multirow[t]{3}{*}{ question_Q10 } & \multirow[t]{3}{*}{ Categorical } & \multirow{3}{*}{$\begin{array}{l}\text { What do you think is the influence of social media on COVID-19 ( A-Posi- } \\
\text { tive, B-Negative, C-Neutral) }\end{array}$} & $A-60$ & $49.2 \%$ \\
\hline & & & B-42 & $34.4 \%$ \\
\hline & & & $C-20$ & $16.4 \%$ \\
\hline \multirow[t]{4}{*}{ question_Q11 } & \multirow[t]{4}{*}{ Categorical } & \multirow{4}{*}{$\begin{array}{l}\text { What would be the best platform for the latest information on COV- } \\
\text { ID-19? (A-Social media, B-Publications, C-WHO website, D-Healthcare } \\
\text { professionals) }\end{array}$} & A-49 & $40.2 \%$ \\
\hline & & & B-34 & $27.9 \%$ \\
\hline & & & C-99 & $81.1 \%$ \\
\hline & & & D-51 & $41.8 \%$ \\
\hline queation_Q12 & Numeric & $\begin{array}{l}\text { How important is it to follow necessary protocols for its prevention? } \\
\text { (Scale from } 1 \text { to } 10 \text {, with } 10 \text { being the highest) }\end{array}$ & $\begin{array}{l}\text { Mean: } 9.95 \pm 0.252 \\
\text { (Min-Max): }(8-10)\end{array}$ & \\
\hline \multirow[t]{6}{*}{ question_Q13 } & \multirow[t]{6}{*}{ Categorical } & \multirow{6}{*}{$\begin{array}{l}\text { Best means of management of COVID-19? (A-Freak out, B-Stay calm, C- } \\
\text { Take precautions, D-Follow proper sterilization, E-Disinfect all surfaces } \\
\text { effectively, F-Wear disposable masks) }\end{array}$} & $A-3$ & $2.5 \%$ \\
\hline & & & B-94 & $77.0 \%$ \\
\hline & & & $C-119$ & $97.5 \%$ \\
\hline & & & D-102 & $83.6 \%$ \\
\hline & & & $E-101$ & $82.8 \%$ \\
\hline & & & F-93 & $76.2 \%$ \\
\hline \multirow[t]{3}{*}{ question_Q14 } & \multirow[t]{3}{*}{ Categorical } & \multirow{3}{*}{$\begin{array}{l}\text { Is it necessary to continue practicing at the heat of the moment? (A-Yes, } \\
\text { B-No, C-Maybe) }\end{array}$} & A-11 & $9.0 \%$ \\
\hline & & & B-85 & $69.7 \%$ \\
\hline & & & $C-11$ & $9.0 \%$ \\
\hline \multirow[t]{3}{*}{ question_Q15 } & \multirow[t]{3}{*}{ Categorical } & \multirow{3}{*}{$\begin{array}{l}\text { Should the patient be worried to undergo any procedure? (A-Yes, B-No, } \\
\text { C-Maybe) }\end{array}$} & A-46 & $37.7 \%$ \\
\hline & & & B-42 & $34.4 \%$ \\
\hline & & & $C-34$ & $27.9 \%$ \\
\hline \multirow[t]{3}{*}{ question_Q16 } & \multirow[t]{3}{*}{ Categorical } & \multirow{3}{*}{$\begin{array}{l}\text { Patient to be advised to rinse using? (A-Chlorhexidine, B-Hydrogen } \\
\text { peroxide, C-Glutaraldehyde) }\end{array}$} & A-102 & $83.6 \%$ \\
\hline & & & B-21 & $17.2 \%$ \\
\hline & & & $C-14$ & $11.5 \%$ \\
\hline \multirow[t]{4}{*}{ question_Q17 } & \multirow[t]{4}{*}{ Categorical } & \multirow{4}{*}{$\begin{array}{l}\text { What is COVID-19 vulnerable to? (A-Heat, B-Cold, C-Oxidation, } \\
\text { D-Humidity) }\end{array}$} & $A-81$ & $66.4 \%$ \\
\hline & & & B-31 & $25.4 \%$ \\
\hline & & & $C-19$ & $15.6 \%$ \\
\hline & & & D-34 & $27.9 \%$ \\
\hline \multirow[t]{5}{*}{ question_Q18 } & \multirow[t]{5}{*}{ Categorical } & Most vulnerable group of people to COVID-19? (A-Infants, B-Children, & A-88 & $72.1 \%$ \\
\hline & & C-Adults, D-Geriatric, E-Immunocompromised) & B-47 & $38.5 \%$ \\
\hline & & & C-15 & $12.3 \%$ \\
\hline & & & D-100 & $82.0 \%$ \\
\hline & & & $\mathrm{E}-111$ & $91.0 \%$ \\
\hline question_Q19 & Categorical & Precautions to be taken to avoid COVID-19? (A-PPE compulsory, B- & A-48 & $39.3 \%$ \\
\hline & & Cough openly, C-Isolate yourself, D-Avoid public gathering, E-Avoid & B-4 & $3.3 \%$ \\
\hline & & & C-114 & $93.4 \%$ \\
\hline & & & D-118 & $96.7 \%$ \\
\hline & & & $\mathrm{E}-113$ & $92.6 \%$ \\
\hline & & & $\mathrm{F}-29$ & $23.8 \%$ \\
\hline question_Q20 & Categorical & Should the dentist wear an N-95 respirator while treating the patient? & A-100 & $82.0 \%$ \\
\hline & & (A-Yes, B-No, C-Maybe, D-Only if the dentist is comfortable) & $B-3$ & $2.5 \%$ \\
\hline & & & $\mathrm{C}-11$ & $9.0 \%$ \\
\hline & & & D-8 & $6.6 \%$ \\
\hline question_Q21 & Categorical & Should you be worried about COVID-19? (A-Yes, B-No, C-Maybe) & A-99 & $81.1 \%$ \\
\hline & & & B-11 & $9.0 \%$ \\
\hline & & & $\mathrm{C}-11$ & $9.0 \%$ \\
\hline question_Q22 & Categorical & What would you tell your patients about COVID-19? ( A-Nothing, B- & $A-0$ & $0.0 \%$ \\
\hline & & Educate them regarding prevention, C-Tell them that it is scary and stay & B-121 & $99.2 \%$ \\
\hline & & away from everythıng) & $\mathrm{C}-1$ & $0.8 \%$ \\
\hline
\end{tabular}




\section{Discussion}

The spread of COVID-19 in all countries affected has raised major challenges for dentistry and medicine. Wuhan's local government did not immediately understand the importance of Dr Li Wenliang's latest SARS-like disease, but after some initial delay, China's central government engaged in a rapid draconian response that succeeded and delayed the COVID-19 eruption. ${ }^{13}$ The country took exceptional steps in dispatching the personal protective equipment (PPE) to all the healthcare workers. Routine dental treatment was discontinued in January 2020 and was scheduled to return to normal 3 months later. ${ }^{23}$ As advised during the earlier SARS outbreak, only emergency dental treatment was given with advice on strict personal safety and steps to minimize and prevent the output of droplets and aerosols, the use of high-volume aspiration, and others. ${ }^{24}$ COVID-19 usually presents with systemic and/or respiratory manifestations. Some SARS-CoV-2-infected people are asymptomatic and can act as carriers. ${ }^{25}$

Each country has been rapidly developing policies to regulate the COVID-19 pandemic, taking into account various guidelines from the WHO. There is no clear COVID-19 treatment or vaccine in place (May 2020). Resources have also focused on public health initiatives to prevent further transmission of the virus among humans. As India's health care would be quite challenging due to insufficient healthcare workers, precautions by all means is our best way to tackle the situation.

An overview of the data obtained from the survey gives a bird eye view on the concerns. Evidently, all the dentists are aware of COVID-19 and the elementals regarding the pathogen, the disease, and the history on its initial outbreak. Majority of them were updated with information mostly from social media followed by newspapers. In all, 95\% (114) respondents acknowledged COVID19 as a pandemic, while the remaining $2.5 \%$ called it an endemic and epidemic each. Although we are all aware of the key signs and symptoms of the disease being cough and breathlessness, we must recognize that cold is not one of them. ${ }^{6}$ Within weeks of the outbreak of the latest coronavirus disease in China in 2019, false reports and conspiracy theories about the sources spread across the globe, combined with fear mongering, racism, and mass purchasing of face masks, all closely linked to the latest 21st-century "infomedia" ecosystems marked by social media. ${ }^{26}$

It is cardinal to stop this stigma, since it can lead people to conceal their disease and not seek immediate health care. To help people handle anxiety, stigma, and prejudice during COVID-19, WHO offers expert advice and answers to public questionnaire. ${ }^{27}$ The abominable thing about social media is news travel fast, irrespective of whether it is good or bad. In all, $47.5 \%$ of the participants complied with the positive influence of the media, while $16.9 \%$ side with its negative effects and $35.6 \%$ calling neutral. As WHO would give elite and genuine information on COVID-19, it would be the best platform for any updates on the disease according to the participants with 96 possible responses.

The New York Times reminded the world that dentistry had the most risk of any profession in relation to COVID-19 due to potentially close contact with the patient during the procedures. ${ }^{28}$ Therefore, it is utmost important to follow protocol for the prevention of COVID-19. The principal moral response is to salvage lives. It is a moral duty to all healthcare providers to care for their patients. In dentistry, we go to great lengths to choose those to enter the profession that exhibit characteristics of caring, and the general public expect that of us. However, how much risk to dental care professionals is acceptable during the COVID-19 pandemic? We are very familiar with occupational health issues in dentistry, such as hepatitis $B$ and hepatitis $C$, and risk assessment. ${ }^{29,30}$ Thereby taking precaution as a part of management of COVID is the best means of practical management with most number (118) of responses followed by proper sterilization methods (101), disinfecting surfaces, and disposable PPEs, respectively.

Dentistry is familiar with the concept of general precautions for the prevention of cross-infections based on an assumption that we do not know whether or not a patient has the potential for transmission of disease. There was an early report of one case of COVID-19 infection in Germany with transmission through contact with an asymptomatic patient. ${ }^{31}$ An ethical question that arises at this time is to still continue the practice at the heat of the moment? To which we received conundrum responses which sided No with $69.2 \%$, Yes with $9.2 \%$, and Maybe with $12.7 \%$. When posed a question as whether a patient should be concerned to undergo any treatment, approximately $37 \%$ seconded that they should be worried, a $38 \%$ for no, and $28 \%$ for maybe.

It is obvious for any patient to be anxious about the procedures, especially during a high-fledged pandemic. Dental drills cause aerosol and splatter formation that is usually infected with bacteria, viruses, fungi, and blood. ${ }^{32}$ This is a high risk of exposure to the dentists. Standard surgical face masks used in dentistry give about $80 \%$ filtration rate when properly worn and regularly modified. In normal cases, this is good security for elective dentistry, recognizing that the majority of our patients are well. ${ }^{29}$ The use of an FFP3 respirator offers a filtration rate of $99 \%$ of all particles measuring up to $0.6 \mu \mathrm{m} .{ }^{33}$ As bound to the morale of the situation, we have to address the patient, and hence it is indeed a need of the hour to follow precautionary measures, despite the patient being asymptomatic.

Given that the coronavirus can remain alive on surfaces for more than 24 hours, keeping all surfaces clean and sanitized is important. Although this applies to the waiting room, the bathroom, and the front desk, disinfecting the operator as much as possible is particularly important. Common cleaners such as $0.1 \%$ sodium hypochlorite, $0.5 \%$ hydrogen peroxide, or $62-71 \%$ ethanol have all been shown to be efficacious. ${ }^{33}$ From above, we can conclude that COVID-19 is susceptible to oxidation. Since the virus is more prone to oxidation, it would be best advised for the patient to rinse with diluted hydrogen peroxide solution rather than regular chlorhexidine mouth rinse. Chlorhexidine may not be adequate for elimination of 2019-nCoV. Preprocedural mouth rinse containing oxidative agents such as $1 \%$ hydrogen peroxide or $0.2 \%$ povidone is advised. ${ }^{34}$ Although there are few misconceptions regarding the spread of COVID, we the healthcare workers must be aware of the myths. COVID-19 cannot be killed in cold weather. However, it can also be transmitted in hot and humid climates too. Best way of prevention could be to maintain social distancing. ${ }^{35}$

Severe acute respiratory syndromes associated with coronaviruses seem to have a children-sparing pattern as indicated by the SARS-CoV (2003) and MERS-CoV (2012) epidemic literature available. ${ }^{36}$ Infants (87) are more vulnerable to COVID, since their immune system will not be fully developed. While geriatric patients (99) are at high risk of fatality, research concerning COVID-19 has largely been done on clarifying the clinical features. ${ }^{37}$ The same applies to immunocompromised (110) individuals due to obvious reasons. 
As Desiderius Erasmus quotes "Prevention is better than cure," it should be our primary aim to contain the spread of COVID-19. Major things in mind should be to use PEE as a must while maintaining social distancing of at least 3 feet. Cleaning hands regularly and thoroughly with an alcohol-based hand rub or washing them with soap and water. One should not hesitate to isolate oneself and avoid any public gathering and crowded places as a safety measure. Avoid touching eyes, nose, and mouth as hands touch many surfaces and can pick up viruses. If contaminated, they can transfer the virus to your eyes, nose, or mouth which can enter your body and infect you. Make sure to follow good hygiene. ${ }^{13}$ Although only $81 \%$ of the clinicians consider that it is mandatory for the dentists to wear the N95 respirator, it is a crucial part of the PEE which cannot be ignored. Rather than being worried, we should know how to tackle the scenario at our best. As healthcare workers, it is our responsibility to educate our patients and the public about the COVID and to account the virus at our best.

\section{Conclusion}

A preponderance of the dentists were aware of the virus, its survival, and complications and have taken up proper treatment protocols as a precaution for prevention of the disease transmission. Rather than being worried, we should know how to tackle the scenario at our best. As healthcare workers, it is our responsibility to educate our patients and the public about the COVID and to account the virus at our best.

\section{References}

1. Tyrrel DAJ, Almedia JD, Berry DM, et al. Coronavirus. Nature 1968;220(5168):650. DOI: 10.1038/220650b0.

2. Weiss SR, Navas-Martin S. Coronavirus pathogenesis and the emerging pathogen severe acute respiratory syndrome coronavirus. Microbiol Mol Biol Rev 2005;69(4):635-664. DOI: 10.1128/MMBR.69.4.635-664.

3. Lau SKP, Chan JFW. Coronaviruses: emerging and re-emerging pathogens in humans and animals. Lau and Chan Virol J 2015;12(1):209. DOI: https://virologyj.biomedcentral.com/articles/10.1186/s12985015-0432-z.

4. Lu R, Zhao X, Li J, et al. Genomic characterisation and epidemiology of 2019 novel coronavirus: implications for virus origins and receptor binding. Lancet 2020;395(10224):565-574. DOI: 10.1016/S01406736(20)30251-8. https://www.ncbi.nlm.nih.gov/pmc/articles/ PMC7159086/.

5. Coronavirus disease 2019 (COVID-19) Situation Report - 32, who, Coronavirus disease 2019 (COVID-19) Situation Report - 32 Data as reported by 21 February 2020* https://www.who.int/emergencies/ diseases/novel-coronavirus-2019/situation-reports.

6. Coronavirus. World Health Organization https://www.who.int/healthtopics/coronavirus\#tab=tab_1.

7. Infection prevention and control of epidemic- and pandemicprone acute respiratory infections in health care. Geneva: World Health Organization; 2014 Available from: https://apps.who. int/iris/bitstream/handle/10665/112656/9789241507134_eng. pdf?sequence $=1$.

8. Liu J, Liao X, Qian S, et al. Community transmission of severe acute respiratory syndrome coronavirus 2, Shenzhen, China, 2020. Emerg Infect Dis 2020;26(6):1320-1323. DOI: 10.3201/eid2606.200239.

9. Chan JFW, Yuan S, Kok KH, et al. A familial cluster of pneumonia associated with the 2019 novel coronavirus indicating personto-person transmission: a study of a family cluster. Lancet 2020;395(10223):P514-P523. DOI: 10.1016/S0140-6736(20)30154-9.
10. Li Q, Guan X, Wu P, et al. Early transmission dynamics in Wuhan, China, of novel coronavirus-infected pneumonia. N Engl J Med 2020;382(13):1199-1207. DOI: 10.1056/NEJMoa2001316.

11. Huang $C$, Wang $Y$, Li X, et al. Clinical features of patients infected with 2019 novel coronavirus in Wuhan, China. Lancet 2020;395(10223):497506. DOI: 10.1016/S0140-6736(20)30183-5.

12. Burke RM, Midgley CM, Dratch A, et al. Active monitoring of persons exposed to patients with confirmed COVID-19" - United States, January-February 2020. MMWR Morb Mortal Wkly Rep 2020;69(9):245-246. DOI: 10.15585/mmwr.mm6909e1externalicon.

13. World Health Organization, Report of the WHO - China Joint Mission on Coronavirus Disease 2019 (COVID-19). 2020 https://www.who. int/docs/default-source/coronaviruse/who-china-joint-missionon-covid-19-final-rep ort.pdf source/coronaviruse/who-china-jointmission-on-covid-19-final-report.pdf.

14. Ong SWX, Tan YK, Chia PY, et al. Air, surface environmental, and personal protective equipment contamination by severe acute respiratory syndrome coronavirus 2 (SARS-CoV-2) from a symptomatic patient. JAMA 2020;323(16):1610-1612. DOI: 10.1001/ jama.2020.3227.

15. Modes of Transmission of Virus Causing COVID-19: Implications for IPC Precaution Recommendations: Scientific Brief, 29 March 2020." World Health Organization, World Health Organization, 1 Jan. 1970 apps.who.int/iris/handle/10665/331616.

16. "Infection Control Guidance for Healthcare Professionals about Coronavirus (COVID-19)." Centers for Disease Control and Prevention, Centers for Disease Control and Prevention, 3 June 2020 www.cdc. gov/coronavirus/2019-ncov/hcp/infection-control.html.

17. Rational use of Personal Protective Equipment for COVID-19: Interim guidance, 27 February 2020 https://apps.who.int/iris/bitstream/ handle/10665/331498/WHO-2019-nCoV-IPCPPE_use-2020.2-eng.pdf.

18. Ran L. Risk Factors of Healthcare Workers with Corona Virus Disease 2019: A Retrospective Cohort Study in a Designated Hospital of Wuhan in China. OUP Academic, Oxford University Press; 2020. DOI: academic.oup.com/cid/advance-article/doi/10.1093/cid/ ciaa287/5808788.

19. "Infection Prevention and Control (IPC) for COVID-19 Virus." Open WHO, 10 July 2020, openwho.org/courses/COVID-19-IPC-EN.

20. Wax RS, Christian MD. Practical recommendations for critical care and anesthesiology teams caring for novel coronavirus (2019-NCoV) patients. Canad J Anesth/J Canad D'anesthésie 2020;67(5):568-576. DOI: 10.1007/s12630-020-01591-x.

21. Lan $L, X u D, Y e G$, et al. Positive RT-PCR test results in patients recovered from COVID-19. JAMA 2020;323(15):1502. DOI: 10.1001/ jama.2020.2783.

22. Ather A, Patel B, Ruparel NB, et al. Coronavirus disease 19 (COVID-19): implications for clinical dental care. J Endod 2020;46(5)):584-595. DOI: 10.1016/j.joen.2020.03.008.

23. Meng L, Hua F, Bian Z. Coronavirus disease 2019 (COVID-19): emerging and future challenges for dental and oral medicine. J Dent Res 2020;99(5):481-487. DOI: 10.1177/0022034.

24. Li RW, Leung KWC, Sun FCS, et al. Severe acute respiratory syndrome (SARS) and the GDP. Part II: implications for GDPs. Br Dent J 2004;197(3):130-134. DOI: 10.1038/sj.bdj.4811522.

25. Bell DJ, Radiopedia https://radiopaedia.org/articles/covid-193?lang=us.

26. Depoux A, Martin S, Karafillakis E, et al., The pandemic of social media panic travels faster than the COVID-19 outbreak https://academic. oup.com/jtm/article/27/3/taaa031/5775501.

27. Roy D, Tripathy S, Kar SK, et al., Study of knowledge, attitude, anxiety \& perceived mental healthcare need in Indian population during COVID-19 pandemic https://www.sciencedirect.com/science/article/ $\mathrm{pii} / \mathrm{S} 1876201820301945$.

28. Lazaro. G, The workers who face the greatest coronavirus risk. The New York Times https://www.nytimes.com/interactive/2020/03/15/ business/economy/coronavirus-worker-risk.html. 
29. Coulthard P, Dentistry and coronavirus (COVID-19) - moral decisionmaking https://www.nature.com/articles/s41415-020-1482-1\#Sec5.

30. Moodley R, Naidoo S, Wyk JV. The prevalence of occupational health related problems in dentistry: a review of the literature. J Occup Health 2018;60(2):111-125. DOI: 10.1539/joh.17-0188-RA.

31. Rothe C, Schunk M, Sothmann P, et al. Transmission of 2019-nCoV infection from an asymptomatic contact in Germany. N Engl J Med 2020;382(10):970-971. DOI: 10.1056/NEJMc2001468.

32. Szymanska J. Dental bioaerosol as an occupational hazard in a dentist's workplace. Ann Agric Environ Med 2007;14:203-207.

33. "Evaluating the protection afforded by surgical masks against influenza bioaerosols: Gross protection of surgical masks compared to filtering facepiece respirators." https://www.hse.gov.uk/research/ rrpdf/rr619.pdf.
34. What dental practitioners need to know about CORONAVIRUS and precautions to be taken https://www.straumann.com/en/discover/ youtooth/article/education/2020/covid-19.html.

35. Advise for public on COVID-19 Coronavirus disease (COVID-19) advice for the public: Mythbusters.

36. Stockman LJ, Massoudi MS, Helfand R, et al. Severe acute respiratory syndrome in children. Pediatr Infect Dis J 2007;26(1):68-74. DOI: 10.1097/01.inf.0000247136.28950.41. https://journals.Iww.com/pidj/ Abstract/2007/01000/Severe_Acute_Respiratory_Syndrome_in_ Childre n.14.aspx.

37. Leung $C$. Risk factors for predicting mortality in elderly patients with COVID-19: a review of clinical data in China. Mech Ageing Dev 2020;188:111255. DOI: 10.1016/j.mad.2020.111255. 